\title{
Research on college students' entrepreneurial risk in the perspective of entrepreneurial motivation
}

\author{
Wang Fang \\ Industrial policy and management \\ research center \\ School of Management, WUST \\ Wuhan, China \\ 57095788@qq.com
}

\author{
Chen Li \\ Industrial policy and management \\ research center \\ School of Management, WUST \\ Wuhan, China \\ 278749290@qq.com
}

\author{
Rao Dekun \\ Industrial policy and management \\ research center \\ School of Management, WUST \\ Wuhan, China \\ 478228445@qq.com
}

\begin{abstract}
Firstly, according to Maslow's hierarchy of needs, the entrepreneurial motivations of college students are divided into three levels which are the motivations of the existence need, value need and society need. Then the degree of the entrepreneu rial risks is analyzed under these three levels of motivations. Finally, some suggestions of the risk aversion are put forward.
\end{abstract}

Keywords—College students; Entrepreneurial risk; Entrepreneurial motivation; Entrepreneurial education

\section{INTRODUCTION}

Encouraging college students to take entrepreneurship is one of the important policy orientations. In recent years, in our country, college students' entrepreneurship is more and more important in promoting economic growth and absorbing employment. At the same time, the entrepreneurship can make contemporary college students to realize their own value and ideal, exercise the knowledge and redefine their life. Today, college students' entrepreneurship has become a new theme and a field of common concern in all sectors of society. However, the success rate of college students' entrepreneurship in China is not very well. It is reported that the average annual success rate of college students starting their own undertakings is only $2 \%$, well below the $30 \%$ success rate of average entrepreneurship[1]. The education of entrepreneurship risk makes college students to understand the risk clearly and to cope with it more effectively, and to improve the success rate of entrepreneurship.

Scholars have achieved fruitful research results on the environment, education, risk and copping measures of entrepreneurship. Such as the entrepreneurship predicament and countermeasure of seven universities graduates from Subei region and Jiangsu college in China were analyzed based on the ISM model[2], and the college students' entrepreneurial process in China are researched based on Timmons mode [3] , and the factors of entrepreneurial motivation are studied and so on. But there are little reviews to research entrepreneurial risk from entrepreneurial motivation. It is a new research perspective to recognize and avoid the risk of starting a business with the motivation.

\section{ANALYSIS OF ENTREPRENEURIAL MOTIVATION OF COLLEGE STUDENTS}

Entrepreneurial motivation is the starting point and foundation of starting a business. Entrepreneurs are the core of entrepreneurial activities. If you want to succeed in starting a business, you must first know yourself correctly, set up the right motivation, and correctly understand the entrepreneurial process.

To entrepreneurial motivation, Shane thought that entrepreneurial success depends on the entrepreneurial decision-making, since different decision makers has different cognition to the opportunity to lead to different decisions[4]. Shane also put forward that the cognition of opportunity is a reflection of innovation motivation. He thought entrepreneurial motivation reflects the embodiment of the entrepreneur personality traits which includes six aspects of goal setting, accomplishment, risk tendency, the fuzzy tolerance, locus of control and self-efficacy. Based on Shane's research, Taormina found the relationship between entrepreneurial motivation and entrepreneurial traits, and pointed out successful entrepreneurial traits includes the desire for success and optimism about life[5]. Hussain analyzed the business behaviors of the four groups of college students to find that the professional knowledge and work experience are the key factors that affect their entrepreneurial motivation[6]. Basu \&Virick explored the entrepreneurial motivation using the theory of planned behavior, and he pointed out that the entrepreneurial motivation of college students is influenced by the desire of individual, the expectation of the family and the determination to complete the business[7]. Luo studied the path of entrepreneurship motivation and pointed out that the interest is one of the sources of motivation for entrepreneurship[8]. Zhao \& Chen pointed out that the entrepreneurial motivation of college students is diversified, which is influenced by social value orientation, personal ideal, economy and other factors[9]. Lu pointed out that the biggest motivation for college students to start a business is to exercise their ability[10].

This research was financially supported by the provincial teaching research project in Hubei (No.2015235) and by the industrial policy and management research center.. 
According to the study of the above, the most common motivation of college students is to gain greater economic benefits, to test self-knowledge, to realize self-ideal, to realize self-worth, to find interests, to challenge self, to prepare for employment, and to reduce the financial burden of the family. According to Maslow's hierarchy theory, this paper divided the entrepreneurial motivations into three levels as shown in table 1.

TABLE I. THE THREE LEVELS OF THE ENTREPRENEURIAL MOTIVATIONS

\begin{tabular}{|l|l|}
\hline \multicolumn{1}{|c|}{ Level } & \multicolumn{1}{c|}{ Interpretation } \\
\hline $\begin{array}{l}\text { Survival needs (to gain greater } \\
\text { economic benefits and reduce } \\
\text { the family burden) }\end{array}$ & $\begin{array}{l}\text { In order to cope with the high cost, some college students choose part-time during, and some } \\
\text { choose entrepreneurship. The entrepreneurship not only can make full use of university knowledge, } \\
\text { but also has higher economic interests and more freedom. }\end{array}$ \\
\hline $\begin{array}{l}\text { Value needs (interest, } \\
\text { fulfillment and self-worth) }\end{array}$ & $\begin{array}{l}\text { Because many college students have certain knowledge accumulation, courage, passion, and daring } \\
\text { to try and challenge. So, more and more college students will start their own business according to } \\
\text { their hobbies, and test their self-worth or entrepreneurial ideal. }\end{array}$ \\
\hline $\begin{array}{l}\text { Social responsibility } \\
\text { Accumulating experience, } \\
\text { absorbing employment) }\end{array}$ & $\begin{array}{l}\text { Employment pressure has become one of major problems in today's society. What's more the } \\
\text { nation, society and schools also encourage college students to start their own business by policies, } \\
\text { funding and coaching. So many students are trying to start a business to promote employment. }\end{array}$ \\
\hline
\end{tabular}

\section{ANALYSIS OF THE ENTREPRENEURIAL RISK BASED ON MOTIVATIONS}

Based on the research on the entrepreneurial risk of college students at home and abroad, there are three kinds of main risk which are the project risk, the team risk, and the management risk. The degree of these three risks is closely linked with the entrepreneurial motivation, and the relationships between them are analyzed in the following.

\section{A. The project risk under different entrepreneurial motivations}

The main entrepreneurial motivation of college students is to gain economic benefits and to reduce the burden of family. However, operating a new business needs a constant investment in money. Therefore, college students are easy to give up the projects for the financial pressure, especially in the first year and the third year when the pressure is the biggest in the life cycle. In practice, there are $72 \%$ of college students who interest in entrepreneurship, but there are $75 \%$ of college students to choose the employment, and only $10 \%$ of students choose entrepreneurship. So the project risk is high for college students, especially for the student whose motivation is survival needs. The relationship between the project risk and motivation are shown in Fig 1(a).

\section{B. The team risk under different entrepreneurial motivations}

College students' entrepreneurial motivations are diversified. Everyone in the entrepreneurial team has their own main pursuit. Therefore, in the process of entrepreneurship, there are many different objectives which are difficult to each of the entrepreneurial team. In the middle and late stage of enterprise development, the team is easy to be disbanded because diversified objects, and then the business is broken down. The members in college students' entrepreneurial teams are friends or classmates generally. They have different professional skills and different contribution for the business. Thus the standard of interest distribution is difficult to satisfy the requirements of all people. What's more, the entrepreneurial goals are not clear in the early days, and the entrepreneurs are self-seeking, so the risk on the division of entrepreneurial teams among college students is very high. And the relationship between the team risk and motivation are shown in Fig 1(b).

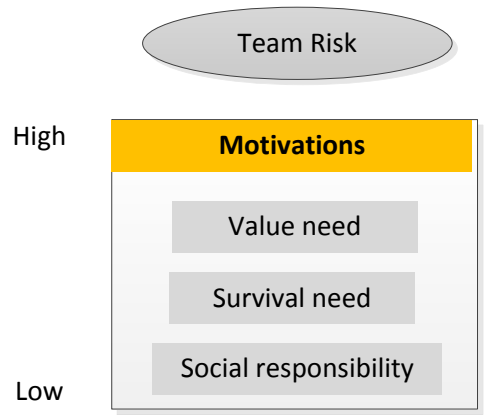

(a) Project risk

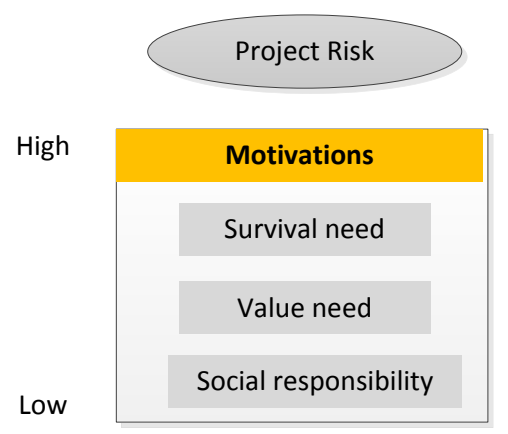

(b) Team risk

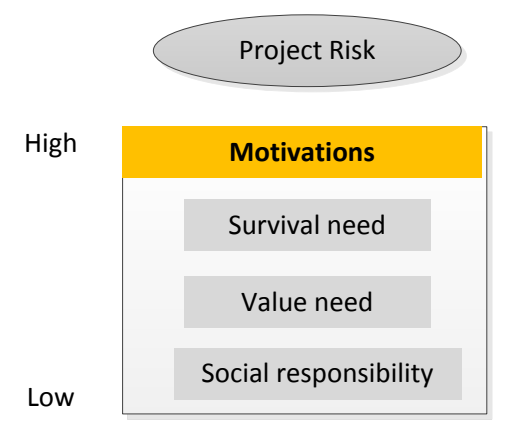

(c) Management risk

Fig 1. The degree of entrepreneurial risks under different motivations 


\section{The management risk under different entrepreneurial motivations}

College students lack experience in management and operation, and they want to realize their own value by entrepreneurship. College students' entrepreneurial teams are constituted based on the relationship rather than the ability, which is irrational in the structure of the ability. In addition, college students are in an age of high-spirited and vigorous, courage, confidence, and no one wants to be led and managed. As a result, the team members have difficulty in unity. So the management risk is also high for college students, especially for the student whose motivation is survival needs. The relationship between the project risk and motivation are shown in Fig 1(c).

\section{SUGGESTIONS ON THE RISK AVERSION}

The entrepreneurial risk is the highest in the survival needs, and it is the lowest in the social responsibility. Therefore, in the entrepreneurship education we should emphasize to cultivate the correct entrepreneurial motivation, such as to undertake the social responsibility and to realize ones value. At the same, when the nation gives the active polity and the social provides the financial assistance, the survival risk will be greatly reduced and the success of college students' entrepreneurships will be increased greatly. Moreover, strengthening the entrepreneurship practice for college students can also improve the success of college students' entrepreneurships. College students have been studying for more than a decade. They generally have more theory knowledge and lack of practical experience, whereas the entrepreneurship needs the knowledge of theory and practice simultaneously. So the entrepreneurial students should strengthen their practice skills before starting a business.

\section{SUMMARY}

According to Maslow's hierarchy of needs, the entrepreneurial motivation of college students can be divided into three levels which are the motivations of the existence need, value need and society responsibility. The degree of the entrepreneurial risks is different under different motivations, and the risk under society responsibility is the minimal while the risk is the biggest under society responsibility. So the effective measures about the risk aversion are to enhance the level of entrepreneurship, improve the polity of nation, increase the capital supply of social, as well as give more chances for students' practical. In future research, we should study the motivation and behavior of college students from psychology and organizational behavior, and more new measures to strengthen the motivation and enthusiasm need to be further research to improve the success rate of the students' entrepreneurship.

\section{REFERENCES}

[1] MvCOS Institute. The employment report of Chinese university students in 2010[M]. MvCOS Institute, 2010.11-21.

[2] He HY, The dilemma and countermeasure of college students[J]. Chinese University Technology Transfe. 5 (2011)68 -69.

[3] Zhu GX. On the relationship between entrepreneurship motivation and entrepreneurship model of college students[J]. Education and Society, 3 (2009)12-18.

[4] Shane S., Venkataraman S., The promise of entrepreneurship as a field of research[J].Academic of Management Review, 1 (2000)217-226.

[5] Taormina R, Sammi K.L, Measuring Chinese entrepreneurial motivation ersonality and environmental influences [J]. International Journal of Entrepreneurial Behavior \& Research, 13(2006):200-221.

[6] Hussain J, Millman C, Scott J, Ethnic minority graduate entreprene urs in the UK [J].INDUSTRIAL\&HIGHER EDUCATION, 2007.23-24.

[7] Basu A., Virick M., Assessing Entrepreneurial Intentions Amongst Students: A Comparative Study [J]. Peer-reviewed papers, 4 (2007)79-86.

[8] LuoL. The path analysis of entrepreneurial motivation of college students - based on the empirical analysis of entrepreneurial motivation of college students in wuhan university[J], Journal of social practice, 3 (2014)28-38.

[9] Zhao Q, Chen XY. Study on psychological analysis and countermeasure of college students' entrepreneurship[J]. Wei shixian agent, 8 (2014)44-46.

[10] Lv ZQ. Analysis of college students' entrepreneurial motivation and its influencing factors[J]. Journal of hubei institute of technology, 34(2014)57-61. 